\title{
Feed Intake Regulation by Physical and Chemical Diet Properties and Feeding Strategies in Ruminants
}

\author{
Akbar Nikkhah \\ Faculty of Agricultural Sciences, University of Zanjan, National Elite Foundation, Iran
}

*Corresponding Author: Akbar Nikkhah, Faculty of Agricultural Sciences, University ofZanjan, National Elite Foundation. Iran

\begin{abstract}
Feed intake is regulated by a number of dietary and feeding management factors. Physical and chemical properties of dietary fiber and forage to concentrate ratio are amongst the most important dietary factors controlling feed intake. The important feeding strategies regulating feed intake in high-producing ruminants include feeding frequency, feeding sequence, and feeding timing. These factors independently or in interaction with other factors influence feed intake and its diurnal rhythms in ruminants. The quantification of such influences requires future research.
\end{abstract}

Keywor ds: Feed Intake, Regulation, Diet, Ruminant, Feeding strategy

\section{1. ОВJECTIVE}

The objective of this article was to review main dietary and feeding management factors controlling feed intake in high-producing ruminants.

\section{Phys ical and Chemical Properties of Dietary Fiber and Forage to Concentrate RATIO}

The diet fiber content can be defined by the dietary level of the cell wall (Blaxter et al., 1961) or more informatively by the cell wall and its physical properties (Mertens, 1997). The physical properties of dietary fiber include, but are not limited to, the cell contents such as starch, pectins and sugars, also fiber bulkiness, and its chemical integration with indigestible portions such as lignin and condensed tannins (Van Soest, 1994). Forage type, maturity at harvest, and post-harvest treatment can affect the physical and chemical properties of forage fiber. Khorasani et al. (2001) fed late-lactation cows either alfalfa silage or bromegrass silage at either 65 or $50 \%$ dietary inclusion rate. Feeding the diets with higher (43\% NDF) compared to lower (40.5\% NDF) F:C tended to reduce dry matter intake (DMI). Robinson and McQueen (1997) manipulated fiber fermentability by feeding high and low quality alfalfa silage in midlactation cows. Fiber intake increased and DMI tended to increase as the TMR fiber fermentability increased. This shows that NDF fermentability affects DMI and, hence, can be used to predict DMI. Moreover, the interaction of dietary fiber and the stage of lactation impacts DMI. Friggens et al. (1998a) fed lactating cows a higher concentrate diet formulated to meet their nutrient requirements and a lower concentrate diet designed to limit energy intake. The intake of the higher concentrate diet depended on milk yield. The intake of the lower concentrate diet, however, did not change throughout lactation. This probably suggests a link between dietary concentrate level, and likely rumen capacity, with DMI (Conard et al., 1964). Knowledge of quantitative relationship between the dietary F:C and DMI is required before the F:C can be used to predict DMI at different stages of lactation. The impacts on DMI of diet physical properties must also consider fiber digestibility, animal production level, and lactation stage.

\section{Feeiding Frequency and Sequence}

Feeding frequency (FF) has received a great deal of attention by ruminant nutritionists (Nocek, 1987; NRC, 2001). A multitude of factors such as dietary F:C, TMR vs. component feeding, cereal grain type, processing method, cow productivity, ambient temperature, and dietary use of bST and their interactions mediate cow response to FF. Once the individual and interactive effects outlined above are determined, animal response to FF may be quantified. 
French et al. (1990) showed no effects of feeding dietary concentrate either 2 or 12 times daily on DMI in early lactation cows. Delivery of either a cubed or uncubed ration two or four time daily did not affect DMI in midlactation cows (Klusmeyer et al., 1990). Shabi et al. (1998) reported no differences in DMI of cows fed twice and four times daily. In another study, Shabi et al. (1999) found that DMI increased by four times compared to twice delivery of a corn-based TMR. They attributed the higher DMI of the more frequently fed cows to greater total tract DM digestibility. Dhiman et al. (2002) observed no significant effects of four times vs. once daily delivery of a corn grain-based TMR on DMI of midlactation cows. Monitoring the 24-h patterns in feed intake may help explain the underlying mechanisms of DMI response to FF. Recently, DeVries et al. (2005) showed that increasing FF from once to twice or from twice to four times daily increased average eating time per cow in group-fed lactating cows. The more frequently fed cows had a more even distribution of eating over the 24-h period. Also, feed sorting was reduced by the more frequent feed delivery. This may enhance fiber digestibility (Ørskov, 1999). Nevertheless, the eating activity reported by DeVries et al. (2005) was based on the number of cows present at the feed bunk and not the amount of feed consumed within a certain time interval by individual cows. Therefore, it remained unknown if FF affected DMI. In a more recent study, feeding early-lactation dairy cows once instead of four times daily increased DMI under uncompetitive feeding and housing environments (Nikkhah, 2013). This finding demonstrated that increasing FF is not necessarily beneficial and that delivering the whole daily TMR at once could improve feed intake of high-producing lactating cows in early-lactation.

Reduced 24-h variation in eating may reduce 24-h variations in rumen $\mathrm{pH}$ (French et al., 1990), which may reduce the risk of subacute rumen acidosis and increase fiber digestibility (Nocek, 1987; Ørskov, 1999). However, before such a theoretical cascade turns into an on-farm reality, the more frequent feeding must prevent or reduce the time during which the rumen $\mathrm{pH}$ drops to the detrimental point to microbial metabolism.

The feeding sequence of forage and concentrate is another variable affecting feed intake (Nocek, 1992; Robinson, 1989). Nocek (1992) observed a tendency for increased DMI when a mixture of grain and protein meal was delivered at $0700 \mathrm{~h}$ followed by forage delivery at $1000 \mathrm{~h}$, compared to when forage was delivered first. Usually, offering forage prior to concentrate early in the morning is believed to form an amply developed rumen fiber mat, which can in turn stimulate salivation (Robinson, 1989) and may reduce the risk of subacute rumen acidosis (Voight et al., 1978). As a result of the controlled rumen $\mathrm{pH}$, DMI may not drop (Allen, 2000). Again, before the effect of feeding sequence on DMI can be observed, the detrimental low rumen $\mathrm{pH}$ must occur.

\section{TIME OF FEEDING (TF)}

There is a scarcity of literature on the effect of TF on 24-h patterns in feed intake and feeding behavior of once-daily fed cows under normal ambient temperatures. Also, data on DMI response to TF under thermoneutral ambient temperatures is very rare. Robinson et al. (1997) fed lactating cows $67 \%$ of the TMR at $0800 \mathrm{~h}$ and $33 \%$ of it at $1800 \mathrm{~h}$. In addition they fed a protein supplement (about $15 \%$ of estimated DMI) at either $0830 \mathrm{~h}$ or $0030 \mathrm{~h}$. Feeding the protein supplement at $0030 \mathrm{~h}$ instead of $0830 \mathrm{~h}$ increased DMI of the protein supplement and numerically increased total DMI (16.92 vs. $15.94 \mathrm{~kg} / \mathrm{d})$. The numerical increase in DMI was associated with significant increases in rumen DM, OM, and CP digestibility. It was suggested that the midnight compared to morning delivery of the protein supplement stabilized rumen fermentation. Aharoni et al. (2005) fed lactating cows under heat stress four times during either the day or in the evening. The day-fed cows received the diet $30 \%$ at $0615 \mathrm{~h}, 20 \%$ at 1000 $\mathrm{h}, 25 \%$ at $1530 \mathrm{~h}$, and $25 \%$ at $1900 \mathrm{~h}$; whereas the evening-fed cows received the diet $20 \%$ at $0615 \mathrm{~h}$, $30 \%$ at $1530 \mathrm{~h}, 25 \%$ at $1900 \mathrm{~h}$, and $25 \%$ at $2100 \mathrm{~h}$. Evening-fed group had no access to feed for $5.5 \mathrm{~h}$ during the day. Limiting the feed access during the day and shifting the majority of eating time to the evening hours reduced both DMI and energy expenditure. Under cold weather, feeding at $2000 \mathrm{~h}$ instead of $0900 \mathrm{~h}$ improved growth rate in beef steers without affecting DMI (Small et al., 2004). Kennedy et al. (2004) fed heifers at either 0900 or $2000 \mathrm{~h}$ in winter $\left(<-15^{\circ} \mathrm{C}\right)$ and found no significant effects of TF on DMI. Evening feeding, however, improved feed efficiency during backgrounding period, compared to morning feeding. Ominski et al. (2002) exposed cows to 5-d phases of thermoneutral $\left(24^{\circ} \mathrm{C}\right.$ during the day and $20^{\circ} \mathrm{C}$ overnight) and heat stress $\left(32^{\circ} \mathrm{C}\right)$ conditions followed by a 5-d recovery period. In the stress period, the temperature rose steadily up to $32^{\circ} \mathrm{C}$ between 0700 to $1000 \mathrm{~h}$, remaining at $32^{\circ} \mathrm{C}$ until $1800 \mathrm{~h}$, but it was reduced down to $20^{\circ} \mathrm{C}$ for the rest of the 24-h period. Despite no overall effect, DMI in the evening-fed cows was reduced during the heat stress phase (Ominski et al., 2002). Altogether, 
the DMI response to TF in the above-mentioned studies was most probably due to the changes in animal thermodynamics. Under thermoneutral conditions, feed delivery in evening instead of morning improved DMI in primiparous cows but not in multiparous dairy cows (Nikkhah et al., 2010). In both primiparous and multiparous dairy cows, evening instead of morning feeding increased eating rate and, as a result, increased feed intake within 3-h post-feeding in two studies (Nikkhah et al., 2008; Nikkhah et al., 2010).

\section{IMPLICATIONS}

Dietary and feeding management factors affecting feed intake regulation in high-producing ruminants were reviewed. These factors include dietary fiber physical and chemical properties, forage to concentrate ratio, feeding frequency and sequence, and feeding timing. Research is needed to address how these factors independently or in interaction with other factors affect feed intake and its diurnal rhythms.

\section{ACKNOWLEDGMENTS}

Thanks to the Iranian Ministry of Science Research and Technology, and National Elite Foundation.

\section{REFERENCES}

Aharoni, Y., A. Brosh, and Y. Harari. 2005. Night feeding for high-yielding dairy cows in hot weather: effects on intake, milk yield and energy expenditure. Livest. Prod. Sci. 92: 207-219.

Allen, M. S. 2000. Effects of diet on short-term regulation of feed intake by lactating dairy cattle. J. Dairy Sci. 83: $1598-1624$.

Blaxter, K. L., F. W. Wainman, and R. S. Wilson. 1961. The regulation of food intake by sheep. Anim. Prod. 3:51-61.

Conrad, H. R., A. D. Pratt, and J. W. Hibbs. 1964. Regulation of feed intake in dairy cows. 1. Change in importance of physical and physiological factors with increasing digestibility. J. Dairy Sci. 47:54-62.

DeVries, T. J., M. A. G. von Keyserlingk, and K. A. Beauchemin. 2005. Frequency of feed delivery affects the behavior of lactating dairy cows. J. Dairy Sci 88: 3553-3562.

Dhiman, T. R., M. S. Zaman, I. S. MacQueen, and R. L. Boman. 2002. Influence of corn processing and frequency of feeding on cow performance. J. Dairy Sci. 85: 217-226.

French, N., G. De Boer, and J. J. Kennelly. 1990. Effects of feeding frequency and exogenous somatotropin on lipolysis, hormone profiles, and milk production in dairy cows. J. Dairy Sci. 73: 1552-1559. Friggens, N. C., G. C. Emmans, I. Kyriazakis, J. D. Oldham, and M Lewis. 1998a. Feed intake relative to stage of lactation for dairy cows consuming total mixed diets with a high or low ratio of concentrate to forage. J. Dairy Sci. 81: 2228-2239.

Kennedy, A. D., R. D. Bergen, T. J. Lawson, J. A. Small, and D. M. Veira. 2004. Effects of evening feeding and extended photoperiod on growth, feed efficiency, live animal carcass traits and plasma prolactin of beef heifers housed outdoors during two Manitoba winters. Can. J. Anim. Sci. 84: 491-500.

Khorasani, G. R., E. K. Okine, and J. J. Kennelly. 2001. Effects of forage source and amount of concentrate on rumen and intestinal digestion of nutrients in late-lactation cows. J. Dairy Sci. 84: 1156-1165.

Klusmeyer, M. R. Cameron, G. C. McCoy, and J. H. Clark. 1990. Effects of feed processing and frequency of feeding on ruminal fermentation, milk production, and milk composition. J. Dairy Sci. 73: 3538-3543.

Mertens, D. R. 1997. Creating a system for meeting the fiber requirements of dairy cows. J. Dairy Sci. 80: 14631481.

Nikkhah A. 2013. Feeding frequency interfacing tradition and modernity in dairy production: fee ding behavior insights. J. Anim. Poultry Sci. 2(4):91-97.

Nikkhah, A., C. Furedi, A. Kennedy, K. Wittenberg, J.C. Plaizier. 2010. Feed delivery at 2100 h vs. 0900 h for lactating dairy cows. Can. J. Anim. Sci. 91(1):113-122.

Nikkhah, A., C. Furedi, A. Kennedy, G. Crow., J. Plaizier. 2008. Effects of Feed Delivery Time on Feed intake, Rumen Fermentation, Blood Metabolites and Productivity of Lactating Cows. J. Dairy Sci. 91:1-12.

Nocek, J. E. 1992. Feeding sequence and strategy effects on ruminal environment and production performance in first lactation cows. J. Dairy Sci. 75: 3100-3108.

Nocek, J. E. 1987. The influence of feeding frequency on ruminal parameters and production response in dairy cattle. Prof. Anim. Sci. 2:69.

NRC. 2001. National Research Council. Nutrient Requirements of Dairy Cattle. 7th rev. ed. National Acad. Sci. Washington, D. C. 
Ominski, K. H., A. D. Kennedy, K. M. Wittenberg, and S. A. Moshtaghi Nia. 2002. Physiological and production responses to feeding schedule in lactating dairy cows exposed to short-term, moderate heat stress. J. Dairy Sci. 85: 730-737.

Ørskov, E. R., and M. Ryle. 1999. Energy Nutrition in Ruminants. 149 pages. Elsev. Sci. Pub. Ltd. Essex, UK.

Robinson. P. H. 1989. Dynamic aspects of feeding management for dairy cows. J. Dairy Sci. 72: 1179.

Robinson, P. H., and R. E. McQueen. 1997. Influence of level of concentrate allocation and fermentability of forage fiber on chewing behavior and production of dairy cows. J. Dairy Sci. 80:681-691.

Robinson, P. H., M. Gill, and J. J. Kennelly. 1997. Influence of time of feeding a protein meal on ruminal fermentation and forestomach digestion in dairy cows. J. Dairy Sci. 80: 1366-1373.

Shabi, Z., A. Arieli, I. Bruckental, Y. Aharoni, S. Zamwel, A. Bor, and H. Tagari. 1998. Effect of the synchronization of the degradation of dietary crude protein and organic matter and feeding frequency on ruminal fermentation and flow of digesta in the abomasum of dairy cows. J. Dairy Sci. 81: 1991-2000.

Small, J. A., A. D. Kennedy, D. M. Veira, W. P. McCaughey, and D. R. Ward. 2004. Time of feeding and growth promotant effects on the winter growth performance and carcass traits of steers. Can. J. Anim. Sci. 84: 133144.

Van Soest, P. J. 1994. Nutritional ecology of the ruminant. 2nd Ed. Cornell University Press., Ithaca, NY.

Voight, J., B. Piatkowski, and R. Krawielitzki. 1978. The effect of the order of roughage and concentrates in feeding on carbohydrate digestion and bacterial protein synthesis in the rumen of the dairy cows. Arch. Tierernaehr. 28: 67.

Citation: A. Nikkhah, "Feed Intake Regulation by Physical and Chemical Diet Properties and Feeding Strategies in Ruminants", International Journal of Clinical Chemistry and Laboratory Medicine (IJCCLM), vol. 4, no. 2, pp. 1-4, 2018. http://dx.doi.org/10.20431/2455-7153.0402001

Copyright: (C) 2018 Authors. This is an open-access article distributed under the terms of the Creative Commons Attribution License, which permits unrestricted use, distribution, and reproduction in any medium, provided the original author and source are credited. 